\title{
Islamist and Islamised Memories in Moroccan Testimonial Prison Literature
}

\begin{abstract}
The Moroccan 'Years of Lead' were a period of rampant state violence between the country's independence in 1956 and the passing of King Hassan II in 1999. Although a robust scholarship has probed its multifaceted aspects, the impact of state violence on specific groups, such as Bahais, Jews, and Islamists, has yet to be included in discussions about the collective memory of postindependence Moroccan. Most importantly, however, in the midst of a relentless glocal war on terror, Moroccan Islamists continue to be marginalised or exclude themselves from the cultural and social memory of state violence. Drawing on al-Mufaḍ̣al al-Maghūtī's memoir Wa ya'lū șawt al-ādhān min jahīm Tazmamart (2009) and Mușțafā al-Ḥasnāwī’s memoir Sujūn wa ashjān (2018), this article provides a conceptualisation of Islamist and Islamised memory of state violence. The distinction between Islamist and Islamised memory demonstrates their different, and even oppositional, stakes in terms of politicisation, religiosity, and partisanship. The article also shows how the publishing media resignifies memories and inscribes them in frameworks of meaning that may not even be relevant to the survivors' experience or concerns.
\end{abstract}

\section{Introduction}

Moroccan Islamists have been given short shrift in discussions of the 'Years of Lead'. The Years of Lead, a period of authoritarianism and rampant state violence which lasted between Morocco's independence in 1956 and the advent of King Mohammed VI's reign in 1999, gave rise to an abundance of testimonial prison literature between 1998 and 2018. ${ }^{1}$ Authored by survivors (sometimes with professional co-writers), ${ }^{2}$ Moroccan testimonial prison literature has been dominated by two groups of prisoners: Marxist-Leninists, who were persecuted from the 1970s through the early 1990s, and the soldiers and officers who, as a

1 This periodisation does not take into account the books published in the 1980s, which, for instance, include Abdellatif Laâbi's Le chemin des ordalies (1982) and 'Abd al-Qādir al-Shāwī's Kāna wa-khawātuhā (2010), among others. Al-Ḥasnāwī's memoir is a post-years-of-lead recording of state violence.

2 El Guabli 2020a, 238-44.

Ә Open Access. (c) 2021 Jeanine Elif Dağyeli, Ulrike Freitag and Claudia Ghrawi, published by De Gruyter. (c) BY-NC-ND This work is licensed under the Creative Commons Attribution-NonCommercial-NoDerivatives 4.0 License. 
punishment for their participation in the coups d'état against King Hassan II in 1971 and 1972, were held incommunicado in the desert prison Tazmamart between 1973 and 1991. Tazmamart prisoners and Marxist-Leninist activists, who bore the brunt of state terror, have since 1999 been at the centre of the memory of state violence, which has become synonymous with their tribulations in arbitrary detention. The pervasive memory of these two categories of survivors has overshadowed the experiences of a sizable number of their contemporary Islamist activists who were similarly repressed. ${ }^{3}$ Even the Equity and Reconciliation Commission (ERC), which was put in place in 2004 to investigate the violations committed during the Years of Lead and provide reparations to the victims, ${ }^{4}$ counted no Islamist members among its seventeen commissioners, and its transitional justice process did not spend significant time on the suffering of Islamists. ${ }^{5}$

I argue that, as a result of the silencing of Islamist experiences of state violence, an effort has emerged to co-opt and Islamise some memories of the Years of Lead. This desire to Islamise memory stands in contradistinction to an already existing, albeit overlooked, Islamist memory. My conceptualisation of "Islamist memory" and "Islamised memory" draws on a comparative study of the al-Mufaḍdal al-Maghūtī’s memoir published by Bilāl al-Talīdī under the title Wa-ya'lū șawt al-adhān min jaḥim Tazmāmart: mudhakkirāt al-mu'taqal alMufaḍal al-Maghūtī (And the call to prayers rises in Tazmamart: al-Mufaḍdal al-Maghūtī’s memoirs, 2009) and Mușțafā al-Ḥasnāwī’s testimony Sujūn waashjān (Prisons and griefs, 2018). ${ }^{6}$ Based on a series of interviews which Tazmamart survivor al-Maghūtī gave to Islamist journalist al-Talīdi, Wa-ya'lū was first serialised in the al-Tajdìd Islamist newspaper before its publication in book form. ${ }^{7}$ Sujūn wa-ashjān, on the other hand, is a collection of essays and autobiographical writings in which former political prisoner al-Ḥasnāwī recounts his experience in prison for what he alleges was a false accusation of terrorism. Obviously, the circumstances and outcomes of these two carceral experiences are different, but both books are rooted in Islam and a distinct Islamist ideology. Notwithstanding this shared Islamist ideology, the degree of politicisation, religiosity, and partisanship varies depending on whether the memoirs portray an Islamist or an Islamised memory.

3 Slyomovics has a very informative chapter on Islamists in her book The Performance of Human Rights in Morocco, 165-94.

4 Instance Équité et Réconciliation 2009, 14-16.

5 Mohsen-Finan 2007, 336.

6 al-Talīdī 2009, al-Ḥasnāwī 2018.

7 El Guabli 2017, 214. 
Islamism is a convoluted concept, one that requires both a nuanced definition and a critical approach to avoid the pitfalls of Islamophobia and facile generalisations about Islam. For political scientist Muhammad Darīf, the adjective "Islamist" refers to a person or a group of people whose political ideology is based on a form of political Islam, with the goal either to establish an alternative regime or integrate the structures of one that already exists. ${ }^{8}$ Sociologist Abdessamad Dialmy has defined Islamism as "any social movement that is based on the exploitation of Islam in order to achieve a political gain and which precisely attempts to achieve power in the name of religion." ${ }^{9}$ Dialmy goes on to demonstrate, albeit in less restrained terms, that "Islamists are obsessed with political power; they are either formerly disillusioned leftists or pan-Arabist activists or members of Sufi brotherhoods who are dissatisfied with Sufism's apoliticism and indifference to power." ${ }^{10}$ Islamism, therefore, is an all-encompassing political project that draws on politicised interpretations of Islam in order to seize power in the name of religion. Dialmy's definition agrees with Darif's, but moves beyond it in drawing attention to the fact that Islamists hail from a variety of social and ideological backgrounds, shedding light on the fact that Islamism is a societal phenomenon that cuts across social classes and intellectual backgrounds. Moreover, Malika Zeghal, a scholar of Islam, has argued that Islamist movements are also "related to state policies and institutional arrangements", cautioning that their existence should not always be construed in opposition to the state. ${ }^{11}$ Zeghal's observation has the advantage of underlining the crucial fact that Islamism and the state are not always in conflict because of the many overlaps that exist between them. In Morocco, the pro-state positions of Hizb al-'Adāla wa-al-Tanmiyya (Justice and Development Party, JDP) Islamist party and the Salafi groups during the Arab Uprisings in 2011 were the clearest example of the convergence of interests that Zeghal pointed to in her analysis. ${ }^{12}$

If Islamism is the use of Islam to wield political power, then even the Moroccan monarchy itself is an Islamist entity. ${ }^{13}$ For, in addition to tracing its lineage to the house of the Prophet Muhammad, the Alawite dynasty, which has

\footnotetext{
8 Ḍaīf 1999, 11.

9 Dialmy 2000, 1.

10 Ibid.

11 Zeghal 2008, xxviii.

12 Hānī 2011.

13 A debate raged in Morocco in March 2020 when Abdellatif Wahbi, the new general secretary of the Authenticity and Modernity Party, declared that "imārat al-mu'minīn islām siyyāsī" (The leadership of the faith is political Islam). See Wahbi 2020.
} 
been ruling Morocco since the seventeenth century, has monopolised religious affairs and used Islam as a marker of its legitimacy against both the left and the recalcitrant Islamist movements since 1970s. ${ }^{14}$ Anthropologist Abdellah Hammoudi has situated the monarchy's religious shift at the end of the $15^{\text {th }}$ century, when Sufi and Sharifian legitimacy began to mix with political authority. ${ }^{15}$ Other scholars have shown how Morocco's institutional memory gradually consolidated around the monarchy, Islam, and Islamic calendars after the country's independence in $1956 .{ }^{16}$ For example, King Mohammed V's death began to be commemorated according to the Islamic calendar, thus placing the monarch "in the chronology of Islam," which reinscribed him in the "holy history". ${ }^{17}$ Furthermore, Article 19 of the Moroccan Constitution, drafted in 1962, defined Morocco as an Islamic state and conferred the title of Amir al-Mu'minin (The Commander of the Faithful) on the monarch, thus conflating the religious and temporal functions of government in the person of the king. ${ }^{18}$ As a consequence, the persona of the Moroccan monarch is presented as an embodiment of the Islamic past in the present. In the spirit of this continuity, the king's Friday and 'i $d$ prayers, as well as charity activities, are commemorations of his ancestors and a constant reminder that Islam is constitutive of Morocco's political identity. ${ }^{19}$ Various other ritualised practices have consecrated this royal Islamism, such as al-Durūs al-ḥasaniyya al-ramaḍanniyya (Ramadan Ḥassanian Seminars), which bring together Muslim scholars from all over the world to give lectures in the presence of the king, and institutions, such as Lajnat al-Quds (al-Quds Committee), which aims, among other things, to keep the Islamic characteristics of the holy city of Jerusalem. Most recently, the creation of Mu'assasat Muhammad al-Sādis li-al-'Ulamā' al-Afāriqa (Mohamed VI Foundation for African 'Ulama) has given this Islamist function a continental dimension. ${ }^{20}$

Given the Moroccan monarchy's quasi-arrogation of Islam, the emergence of Islamist and Islamised memory of state violence poses a challenge to this royal monopoly of religion. Specifically, testimonial prison literature that demonstrates that the state violates the basic human rights of those who work to implement an Islamist vision of the state complicates an area where institu-

14 Darif 1999, 11, El Ayadi 2015, 37.

15 Hammoudi 1997, 54.

16 Valensi 1990, 288-91.

17 Ibid., 291.

18 El Ayadi 2015, 102.

19 Waltz 1995, 106.

20 Mu'assasat Muḥammad al-Sādis lil-‘Ulamā’ al-Afāriqa, 2015. 
tions and language have been shaped by the monarchy since independence. ${ }^{21}$ The monarchy finds itself in an aporetic position between its discursive defence of Islam and its values, on the one hand, and its use of state violence to repress those groups or individuals who attempt to apply these values to government, on the other hand. While it claims Islam and ritualises it to bolster its grip on power, the monarchy also thwarts the endeavours of those Islamists who propose a different societal and political project for Morocco. As a result of this contradiction, both what I conceptualise as Islamist and Islamised memory have wider implications not only for the legitimacy of the Moroccan monarchy's uses of Islam in politics, ${ }^{22}$ but also for the Equity and Reconciliation Process (ERC) that was launched in 2004 to turn the page on past human rights violations in Morocco. The fact that hundreds of Moroccan Islamist activists were subjected to extrajudicial processes after 2003 because of terrorism accusations, in an echo of the Years of Lead, revealed how state violence has not really disappeared, but shifted to target the Islamists as the new enemies of the state. ${ }^{23}$

\section{Islamist memory and Islamised memory of state violence in Morocco}

\section{Islamist memory: Reclaiming the memory of political imprisonment}

Despite the different levels of its exclusion from Moroccan cultural memory, Islamist memory of state violence can be defined as a form of collective memory that highlights the human rights violations suffered by Islamist activists as such. Islamist memory recalls the countless punishments, such as political disappearance, torture, and imprisonment, meted out to activists for no other reason than their commitment to establishing a polity that abides by Islamic law. This memory is Islamist because its carriers were chiefly targeted because of their competition with the state over political Islam. As an experience that was constitutive of Morocco's memory of the Years of Lead, Islamist memory, like all other memories of this violent period, emerged as part of the Moroccan

21 Zeghal 2008, xii.

22 My first attempt at conceptualising 'Islamised memory' can be traced back to my book chapter “Testimony and Journalism: Moroccan Prison Narratives.” See El Guabli 2017, 130.

23 Human Rights Watch 2005a, 13. 
people's political struggle against the monarchy's authoritarianism. Hence, Islamist memory is an essential part of Moroccan society's social and cultural memory. Nevertheless, the lack of substantial Islamist cultural production on these experiences has hampered the creation of an Islamist cultural memory. As De Cesari and Rigney have written, cultural memory "involves the continual production, remediation, and sharing of stories about a past that changes in relation to the new possibilities of interpreting it within shifting social frames operating at different levels." ${ }^{24}$ The absence of a systematic documentary effort among former Islamist prisoners has been detrimental to the creation of an Islamist dimension of Moroccan cultural memory and obstructed the possibilities that it could open up about the Moroccan past. Nevertheless, the very few Islamists who have published memoirs continue to create possibilities for conversation among different memories of political imprisonment in Morocco.

These memory-based dialogues are all the more crucial because they show that no organised or potentially threatening opposition group was safe from state violence during the Years of Lead. Nasserists, Islamists, Jewish activists, Berber activists, Marxist-Leninists, Sahrawis, and the putschists involved in the coups against King Hassan II in 1971 and 1972 were all subjected to inhumane treatment and lengthy prison terms as a consequence of their involvement in politics. ${ }^{25}$ Given their functions within the army, Tazmamart detainees were probably the least politicised of all these groups, but their arbitrary detention and lengthy enforced disappearance transformed them into political prisoners.

Islamist activists were also subjected to state violence, as a direct result of their efforts to put in place an Islamic state. Despite the state's facilitation of the emergence of the Al-Haraka al-Islāmiyya al-Maghribiyya (The Moroccan Islamist Movement, MIM) as a natural ally of the Moroccan state in response to the existence of the Moroccan Marxist-Leninist Movement in $1969,{ }^{26}$ the state turned against the MIM. Although it is referred to as a single movement, the MIM was, in fact, not homogeneous because it was permeated by different currents that shaped its very existence. To explain the different trends and the external and internal factors that governed their emergence, political scientist Muhammad Darif has coined the phrases al-shart al-'āmm (the general context) and al-shart al-khāṣs (the specific context) to elucidate the circumstances that governed the

24 De Cesari and Rigney 2014, 8.

25 Human Rights Watch 2005b "La commission marocaine de vérité: Le devoir de mémoire honoré à une époque incertaine,” 8-9, Slyomovics 2005, Mohsen-Finan 2007, 327-338, Rollinde 2002, EL Guabli 2020b, 81.

26 Darif 1999, 21. 
appearance and evolution of the different uses of Islam in politics by al-Shabìba al-Islāmiyya (The Islamic Youth), al-'Adl wa-al-Ihsān (Justice and Charity Group), al-Badīl al-Hậ̣̄̄ī (The Civilisational Alternative), al-Haraka min ajl alUmma (The Movement for the Umma), and Harakat al-Tawhīd wa-al-Ișlāh (Movement for Unicity and Reform). ${ }^{27}$ The decision to legalise the existence of al-Shabìba al-Islāmiyya in 1969 was determined by, on the one hand, "the general context" of the Moroccan state's fight against Nasserism in the Arab world and, on the other hand, by the "specific context" of struggle against the atheistic Marxist-Leninist movement. ${ }^{28}$ Parallel to its cooperation with the state, al-Shabība al-Islāmiyya developed a secret agenda of jihad against the infidel state, which fostered and supported its existence. ${ }^{29}$ For example, Hakīmī Bilqāsim, one of its former adepts, has underlined the fact that he belonged to al-Shabìba al-Islämiyya because of its call to take up arms against the Moroccan regime. ${ }^{30}$ Because of al-Shabiba al-Islämiyya's propensity to violence, most Islamists, including those who later moved on to create other more inclusive and peaceful organisations, ${ }^{31}$ have carried the stigma of violence with them and became easier targets when the government passed more stringent terrorism laws after the Casablanca bombings on May 16, 2003.

By 1975, Moroccan Islamists of different backgrounds paid a high price for their disagreements with the state. Once the general and the specific contexts that allowed their existence to be tolerated came to an end with the end of Nasserism and the clampdown on Marxist-Leninists, the state seized the next opportunity, offered by the assassination of lawyer and trade union activist Omar Benjelloun by members of al-Shabība al-Islāmiyya, to persecute Islamists. ${ }^{32}$ Although there is much speculation about the state's own involvement in Benjelloun's assassination, ${ }^{33}$ what is certain is the fact that the state security

27 Darif 1999, 8.

28 Ibid., 16-20. I choose to translate al-shart as context instead of condition because the latter does not reflect the larger aspects of Islamisation and the fight against it as the word context does.

29 Ibid., 36.

30 Belqāsim 2005.

31 Several prominent leaders of the JDP were members of al-Shabiba al-Islämiyya. Former Prime Minister Abdelilah Benkirane and his colleague Abdellah Baha played a major role in legalising the status of those who wanted to participate in the political arena through the channels that opened by the state to contain Islamism.

32 Darif 1999, 38-39.

33 See an important first-hand account that revisits this period by former member of alShabība al-Islāmiyya 'Abd Arrahị̄m Mhtād in Al-Ṣabāḥ daily newspaper in May 2020. 
complex exploited his death to repress the Islamist movement, especially its jihadist offshoot. Under King Hassan II, the onslaught on Islamists lasted from the mid-1970s to the 1990s, but the global war on terror in the early 2000s and the terrorist attacks in Casablanca on May 16, 2003 intensified the security campaigns against this nebulous entity that is usually referred to as Islamism. For instance, after the Casablanca attacks in 2003, some 8,000 supposed Islamists were arrested immediately, but only 1,000 of them were officially tried and found guilty of terrorism. The sheer number of people arrested and the harsh treatment of the accused posed crucial questions about the scale, as well as the legality, of the arrests. For example, Taoufik Moussaif Benhammou, a lawyer who has defended many Islamist defendants, declared that "violations of human rights continue. The state kidnaps and interrogates Salafis outside the purview of any law." ${ }^{34}$ Political scientist Ahamed Chaarani wonders "What's happening in Moroccan society? In two years, between 2001 and 2003, 5,000 were arrested for the accusation of being Islamist. 3,600 were released, whereas 1,400 were put on trial." ${ }^{35}$ Using what they called the "sieve strategy", ${ }^{36}$ which means targeting larger numbers of suspects than necessary to find the real culprits, the Moroccan internal intelligence services adopted a process of elimination to release those whom they thought were not guilty of terrorism. The problem with the sieve strategy is that it suspends the presumption of innocence, in requiring suspects to prove their innocence instead of requiring police to gather evidence to prove their guilt. Many innocent people were arrested as a result of this strategy, and political scientist Mohamed Tozy concluded that the state "manages this dossier blindly". ${ }^{37}$ Up until 2018, the Committee of the Defense of Islamist Prisoners had registered the existence of 1,067 Islamist prisoners in Moroccan prisons, including a fifteen-year-old girl accused of being part of a terrorist cell..$^{38}$

The weak presence of Islamists' memory of state violence in Moroccan collective memory of the Years of Lead is detrimental to institution-building and democratisation. After any period of authoritarianism, memory is a rampart against the repetition of human rights violations. However, it seems that the social and cultural amnesia regarding the violations of Moroccan Islamists' human rights created the conditions for both the continuity and repetition of

34 Chaarani 2005, 214.

35 Ibid., 213.

36 Ibid., 214.

37 Ibid.

38 Slimānī 2018. 
these violations. The Moroccan ERC downplayed the repression of Islamists and overlooked their memory in its final report. ${ }^{39}$ Worse still, Islamist activists were being rounded up and mistreated by the Moroccan security apparatus even as the ERC process was underway..$^{40}$ For Drīs Wld al-Qābla, a journalist and political commentator, the massive arrests of Islamist activists on accusations of terrorism "show that the mechanisms that allowed the past violations (police impunity, lack of judiciary independence, and the existence of repressive laws) are not merely a memory of the past", ${ }^{41}$ but rather a practice that survives in present day Morocco. As a result, we can talk of a variable geometry application of the notions of reconciliation and transitional justice from which Moroccan Islamists were excluded.

In the absence of any institutional structure that recognises and sustains Islamist memory of state violence, individual survivors have shown their awareness of the need to uphold the memory of their activism. For instance, Muhammad Haqīīi, a former Islamist prisoner, started an illuminating discussion of the status of Islamist memory in Morocco in 2015. Seizing the opportunity offered by the funeral of a former cellmate, Haqīqī wrote a letter in which he brought attention to Islamist survivors' miserable conditions, writing:

The situation of former Islamist prisoners, who spent the prime of their youth in secret prisons during what is known as the Years of Lead in Morocco [incomplete]. As I was looking at the faces of some of the people present, I felt all the emotions of marginalisation, disregard, and injustice. [Also,] I read in the expressions of their faces and heads, which grey hair has already covered, burning questions about their place in the accelerating events and what role [they can] play in order to sign their life contract and confirm their presence and [think about] how to navigate their social life and its challenges. ${ }^{42}$

Haqīi 1 then asked whether former Islamist prisoners deserved their tragic fate. Haqīii contrasted Islamists' activism with the disproportional violence the state unleashed on them:

[A]ll we did was do something that we believed in [,] to the marrow of our bones, but we were kidnapped as a result and torture was meted out to us, and the courts did not refrain from sentencing us to death, life in prison, and other cruel verdicts in presence or in absentia during unjust trials. ${ }^{43}$

39 Mohsen-Finan 2007, 336.

40 Human Rights Watch 2005b, 45-48, Mohsen-Finan 2007, 332.

41 Wld al-Qābla 2006.

42 Ḥaqīīi 2015.

43 Ibid., para. 1. 
He went on to pose the difficult question of the place former Islamist activists have in Moroccan memory. He wondered if their greatest accomplishment was simply being released from jail, or whether their past sacrifices have qualified them to play a role in today's Morocco. Haqīii asked again whether former Islamist prisoners have "buried the past and turned [the page of] the violations of the past?" 44 In answer to this question, Haqīi ì urged Islamist political prisoners to hold fast to their duty and seize the opportunity to shape Morocco's present through their experience of its carceral past. Haqīii also lamented the disintegration of ties among former Islamist prisoners, a trend which has turned their "sacrifices into mere talk about the past as well as agonies of memories that have no extension in the present." 45

The funeral is a symbolic space where the Islamist memory of the Years of Lead can be addressed. A moment of memory par excellence, the funeral is situated at a crossroads between the life that comes to an end and the afterlife narrative, that will outlast the deceased and shape his memory. It is this moment, which serves as a nexus between life and death, that Haqīi chose to urge those with memories of Islamist oppression to put an end to Moroccan society's erasure of their sacrifices. Also, the funeral is a space in which loss takes its full tangible form, thus amplifying the effect of his speech about memory and amnesia. In urging his former colleagues to take pride in their contribution to Moroccan collective memory after 1956, Haqīiì seemed to encourage them to establish rituals around their memory of the Years of Lead, both to combat their disunity and to guarantee that their contribution to political change in Morocco would be lasting.

Haqīii did not merely sound the alarm about the disastrous situation of Islamist memory in Morocco, he also proposed a project that would allow former Islamist detainees to harness their collective energy to rehabilitate their Islamist memory. Rehabilitating Islamist memory of the Years of Lead would allow those who were imprisoned for their Islamist ideology to "play a role in what is happening in Morocco". ${ }^{46}$ If Islamists do not promulgate their memories of state violence in the public space, Haqīqī argued, they would be "folded in forgetfulness" and others - he was probably alluding to the leftist parties - would collect the fruits of the "sacrifices and struggles that changed Morocco's political trajectory". ${ }^{47}$ In this regard, Haqīqi prodded his colleagues to either revive the

\footnotetext{
44 Ḥaqīqī 2015, para. 1.

45 Ibid., para. 2.

46 Ibid., para. 4.

47 Ibid.
} 
"stillborn" Committee for Solidarity with Islamist prisoners or establish a new structure - all within an Islamist framework - in order to achieve four interconnected objectives: preserving the memory of grave violations of human rights during the Years of Lead, ensuring the state ends its violent practices, working toward the socio-economic rehabilitation of the victims of the Years of Lead and their families, and resolving the outstanding cases of Islamist exiles and victims of the Years of lead. ${ }^{48}$ Although Haqīiì's propositions are clearly addressed to his Islamist colleagues, the order in which they are presented suggests a prioritisation of collective memory above the specific interests of his fellow Islamists.

This insistence on portraying Islamist activism during the Years of Lead as a part of a larger political project that was repressed by the state is significant. It shows a desire to find a place for Islamists' memories within the broader Moroccan collective memory, instead of defining a unique memory that distinguishes them from the rest of society. Rather than removing the Islamist experience from the generalised experience of state violence, Haqīqī exhorts his former colleagues to place their memory in the public sphere, which should not be left to non-Islamists alone to occupy. In the final analysis, Haqīqi warns former Islamists that if nothing is done to redress the Islamist memory of the Years of Lead, "death will cover us all up, one by one, in silence." 49

Haqīiì's intervention would not have been necessary if it were not for the silencing of Islamist memory in Moroccan social and cultural memory. Social memory here refers to various social institutions, including school, families, civil society organisations, and media which, to paraphrase Maurice Halbwachs, serve as a frame of memory, shaping how individuals remember the past as members of a given society. ${ }^{50}$ In contradistinction to social memory, I use cultural memory in reference to the various media and rituals that facilitate access to and transference of memories in a society. Although Aleida and Jan Assmann have a restrictive definition of cultural memory as operating in the long-term at the level of myths and symbols undergirded by institutions, ${ }^{51} \mathrm{cul}$ tural memory in this article refers to the myriad forms of cultural production that reconstruct past experiences or events that are relevant to a wider society's sense of identity and shared ethos. Under this definition, memoirs, biographies and autobiographies of former Moroccan state victims, which I subsume under testimonial prison literature, are part of Moroccan society's collective memory

48 Ḥaqīqī 2015, para. 5.

49 Ibid., para. 6.

50 Halbwachs 1992, 40.

51 Assmann 2008, 111-13. 
of the Years of Lead. As already mentioned, Islamist prisoners have not found their way into Moroccan social and cultural memory with the same ease as other categories of state victims and survivors of arbitrary detention. This exclusion means that Moroccan society has yet to acknowledge Moroccan Islamists' contributions to the political struggle in the country. The previously mentioned Muhammad Haqīì has movingly articulated how Islamists have lost their "social role as political activists" and how Islamist survivors of the Years of Lead are being excluded from "national institutions, such as the National Council for Human Rights". ${ }^{52}$ This complaint demonstrates how amnesia in social and cultural memory could curtail civil rights.

However, rather than placing all the blame for the exclusion of Moroccan Islamists from institutions and social memory on their political opponents, it is important that we also recognise the existence of a certain degree of selfexclusion. As has been previously explained, the lack of publications from Islamist survivors has diminished their presence in the public sphere and has been detrimental to their place in collective memory of state violence, which other stakeholders have successfully associated with their suffering. Although there is nothing that prevents Islamists from contributing to cultural and social memory, two factors can be cited in explaining their absence. First, the fraught atmosphere that both state and partisan media created after the March 16, 2003 terrorist attacks in Casablanca. Media campaigns against them pushed Moroccan Islamists underground and made them increasingly distrustful of the media, which has the power to convey their message to the wider society. Second, the prevalence of the metaphysical concept of al-ibtilä' al-ilāhi (divine trial) among Islamists might also explain their avoidance of the limelight, a phenomenon which has consequently produced an anecdotal and insufficiently chronicled record of the ordeals of various generations of Islamist activists at the hands of the Moroccan state. As a result, Morocco is a country with a vibrant Islamist movement, but with no commensurate presence in social and cultural memory.

\section{Islamised memory: Reorienting the memory of state violence}

In contradistinction to Islamist memory, Islamised memory, as I conceive of it, reclaims experiences of state violence that were not directed at an individual or a group because of their belief in, or activism on behalf of, a political, Islamist

52 Ḥaqīqī 2015, para. 4. 
entity. In fact, Islamised memory recovers tangentially Islamist experiences for political and predicatory purposes, in order to advance the interests of a narrow partisan community. I suggest that while Islamist memory is a result of experiences of political violence at the hands of the state, Islamised memory is a borrowed memory that fits originally non-Islamist experiences of state violence into an Islamist mould or discursive practice that is geared toward the pedagogical and spiritual advancement of the followers of Islamism. As was previously stated, this Islamisation of memory has taken advantage of the quasi-absence of Islamist testimonial writings about arbitrary detention, enforced disappearance, and torture that targeted them as Islamist activists. Thus, Islamised memory not only fills the void left by Islamist activists in cultural memory, but also interprets political events from an Islamist perspective.

Al-Tajdìd, the weekly newspaper of Harakat al-Tawhīd wa-al-Ișlāh (Movement of Unity and Reform), which is the religious wing of the JDP, provides an excellent embodiment of my theorisation of Islamised memory. This newspaper was the platform that al-Talīdī, a well-known Islamist journalist, used to publish his interviews with al-Muffaḍḍal al-Maghūtī, a Tazmamart survivor, in 2009. Even al-Tajdīd's title for al-Maghūtī's narrative interview-testimony indicates a forceful focus on religiosity in Tazmamart. Foregrounding how the call to prayers arose in Tazmamart is the peak of Islamisation. Both the serialised version and the book version of al-Talīdī's recorded conversations with alMaghūtì demonstrate how the lens of the al-Tajdid Islamist newspaper appropriated Tazmamart memory to suit the newspaper's Islamist ideology. Astrid Erll and Ann Rigney have shown that media "are more than merely passive and transparent conveyors of information. They play an active role in shaping our understanding of the past, in "mediating" between us (as readers, viewers, listeners) and past experiences, and hence in setting the agenda for future acts of remembrance within society." ${ }^{53}$ This media effect is clearly at work in alTajdīd's refashioning of al-Maghūtī's lengthy prison sentence in Tazmamart to suit al-Tawhīd wa-al-Ișlāḥ’s agendas.

Moroccan Islamists' testimonial prison literature is both scarce and marginal to discussions of memory and literature. Apart from Ḥakimī Belqāsm's Kitābāt bada'at min hayy al-i'dām (Writings Started in the Death Sentence Quarter, 2005), ${ }^{54}$ Muhạammad Ḥaqīiì's dairies Yawmiyyāt sajīn (A Prisoner’s Journal, 2002),,$^{55}$ and Musțafa al-Ḥasnāwì's Sujūn wa-ashjān (Prisons and Griefs, 2018),

53 Erll and Rigney 2009, 3.

54 Belqāsim 2001.

55 Ḥaqīqī 1995. 
Islamist prison literature is almost non-existent. ${ }^{56}$ Additionally, the very few copies of these books, most often printed at the authors' expense, are limited in reach and difficult to procure. Unlike the survivors of the Tazmamart, among whom iconic survivors such as Muhammad al-Rāys and Aḥmad al-Marzūqī have emerged over the years to become literary celebrities thanks to their writings about prison, the Islamists lack identifiable literary figures who can be associated with the Islamist struggle as a political movement in Morocco. These shortcomings are exacerbated by the media vilification of Islamists, which pushes them into a voluntary silence outside their circles of trust, and impacts their willingness to offer their memories of suffering at the hands of the Moroccan state. The end result of these various factors is the failure of Moroccan Islamists to leave their imprint on debates about state violence in Morocco. Although it may serve the monarchy's as well as some leftist parties' short-sighted interests, this weak presence of Islamist memories of state violence leaves the Moroccan collective memory of the Years of Lead incomplete. Foregrounding Islam in experiences of imprisonment that were not initially due to Islamist activity is only one response to this memory vacuum. This Islamisation of memories compensates for the absence of narratives by Islamists who lived the ordeal of political detention.

The process of the making of Wa-ya'lu embodies how the medium in which a work is published creates Islamises memory. In his introduction to Wa-ya'lu, Bilāl al-Talīdī does not hide his Islamising endeavour; instead he takes pride in the process that led to the memoir's publication. In his preface, al-Talìdi explains that even though he was well-aware of the existence of Tazmamart, it never piqued his interest as a writer until his teacher, Sheikh al-Muqri' al-Idrīsī Abū Zayd, one of the ideologues of the Islamist movement in Morocco and a member of the national council of the JDP, advised him to use the Ramadan series in al-Tajdìd to publish "prison writings and literature of death". ${ }^{57} \mathrm{Abu}$ Zayd guided al-Talīdī to probe "faith positions and psychic thoughts the prisoner and the ailing express in their deathbed." ${ }^{58}$ Abū Zayd was even more specific in recommending that his disciple use the newspaper to serialise al-'Arabī Bāṭma’s al-Raḥil (departure/death, 1995) and Muḥammad al-Rāys’s Min Skhirat

56 As I received the proofs for this chapter, I learned of a highly interesting memoir by Ahmad Lhūu, a former Islamist prisoner. Lhū's memoir is entitled 'Á'id min al-mashraha (A Man Who Returned From the Morgue, 2021), and it has already stirred a lot of debate in Moroccan newspapers about this period.

57 Al-Talīdī 2009, 3.

58 Ibid., 3-4. 
ilā Tazmamart (2000), ${ }^{59}$ "highlighting the religious aspects [of these works] and recognising them" ${ }^{60}$ Neither Bāṭma nor al-Rāys were known to have any Islamist affinities. The former was a popular singer with the legendary band Nās alGhiwān whose profession would have been eradicated by any strict application of sharia law, while the latter was a soldier who assassinated an officer in cold blood at the instigation of his superior during the first coup d'état against King Hassan II in 1971. Under Islamic law, al-Rāys would have been executed in just retribution (al-qișās) for his crime. However, Abū Zayd found their memories of illness and imprisonment instructive and inspiring enough to be worthy of being relayed to al-Tajdìd's Islamist readership.

Abū Zayd's recommendation was only acted upon two years later. Although al-Talīdī never explained why he did not serialise al-Raḥil and Min Skhirāt ilā Tazmamart, ${ }^{61}$ one wonders how this conservative and predication-focused medium would have reshaped the two books. Most importantly, however, it would have illuminated the nature of the edits and adjustments al-Tajdid might have imposed on these literary works in order to shape them to the expectations of the Islamist readership. Nevertheless, instead of republishing al-Rāys and Bātma's memoirs, which clearly did not fit al-Tajdìd's tradition of religious education and preaching, al-Talīdī found his ideal candidate in al-Maghūtī. A perfect candidate because of his religious upbringing (and because he memorised the Quran at an early age), al-Maghūtī was predisposed to fare better among Islamist readers than the two previous candidates. Although these facts about al-Maghūtì's life were widely known, al-Talīì feigned ignorance about them in writing:

I knew nothing about this man except the fragments that were interspersed in the books that were published about the ordeal of Tazmamart. And his picture in my mind did not go beyond the character of a man who was the most consistent among the prisoners in his commitment to doing his prayers. ${ }^{62}$

Unlike al-Rāys and Bāțma, who were ordinary Muslims, al-Maghūtī stood out for al-Talīdī as a man of prayer and extraordinary faith. Al-Rāys has indeed recorded the various ways in which prayer and memorisation of the Quran helped him and his colleagues to survive the plight of enforced disappearance to Tazmamart, but his religious commitment remained within the realm of reason,

\footnotetext{
59 al-Rāys 2001.

60 Al-Talīdī 2009, 4.

61 Bāṭma 2004.

62 Al-Talīdī 2009, 4.
} 
without any excess or exaggeration. Because al-Maghūtī had not spoken to any media, nor did he write his memoirs during the height of interest in stories of human rights violations in Morocco, he was a discovery of sorts in 2009 and his own religious upbringing lent itself to the kind of Islamisation espoused by alTajdìd. Indeed, the potential for Islamisation of al-Maghūtī's memoirs was already contained in both al-Marzūqì's and al-Rāys's respective memoirs. Both Tazmamart survivors emphasised al-Maghūtī's memorisation of the Quran and spoke well of his religious manners. ${ }^{63}$

Al-Talìdī, however, did not acknowledge these elements because he needed to reinvent al-Maghūtī and present him as a paragon of Islamic faith. In a very dramatised rendering of his encounter with al-Maghūtī, al-Talīdī writes

when I met the man, and he told me about his experience from start to end, I didn't feel that he was repeating the scenes and the events that have been narrated in those books [other memoirs about Tazmamart]. I found out that he is recounting from another angle it was the same angle that professor al-Muqri' al-Idrīsī Abū Zayd insisted on me to write about. But this time around I will not be researching in the authors' writings in order to select from them [elements] that relate to the faith aspects, but I will be writing a story that is woven in this spirit from start to end..$^{64}$

There is a process of exclusion and confirmation at work in this quote. First, alTalīdī reduces religiosity in Tazmamart to al-Maghūtī's person. Second, alMaghūtī's existence confirmed the prescience of al-Idrīsī Abū Zayd's suggestion to publish works that demonstrate the power of faith in the face of death or extreme suffering, such as political imprisonment. Consequently, both the exclusion and confirmation processes place faith at the centre of uncovering memories of the Tazmamart ordeal.

Yet foregrounding faith and religiosity is not enough to Islamise the memory of political violence. This Islamisation of memory also requires the creation of a single symbol who can speak for and represent the experience of the group, particularly from a religious point of view. Although there are multiple accounts of prisoners who deepened their faith and became practicing Muslims during their incarceration, ${ }^{65}$ al-Talīdī presented al-Maghūtī as the perfect model of religiosity. Religion was so instrumental for survival and resistance in Tazmamart that over the years the formerly non-practicing officers and soldiers imprisoned in this jail were transformed into deeply pious individuals who took

63 Al-Rāys 2001, 178, al-Marzūqī 2003, 97-98.

64 Al-Talīdī 2009, 4.

65 Al-Rāys 2010, 180-81, al-Marzūqī 2003, 99-101, Serhane 2005, 125-26, BineBine 2009, 67-70. 
comfort in reciting and memorising the Quran, fasting, and regular prayers. ${ }^{66}$ Even the daily schedule and resistance to carceral conditions in Tazmamart were organised around the Quran. Survivor Aḥmad al-Marzūqī has captured the importance of religion in the prisoners' life in writing that the disappeared soldiers "never felt closer to God than [they did] in Tazmamart" ${ }^{67}$ For his part, Aziz BineBine, another Tazmamart survivor, has written that "religion helped [him] to surmount madness and death that always lurked around my illusions and my naiveté." ${ }^{68}$ Even Muhammad al-Rāys, who admits to having had a loose faith before his imprisonment, has highlighted the fundamental role of religion in his survival in Tazmamart. ${ }^{69}$ In al-Rāys's assessment, enforced disappearance taught him and his colleagues the real worth of their life, leading him to conclude that "[i]t is in darkness that a human being can see themselves in their internal mirror." "Confined to jail cells that offered nothing but stench and death, Tazmamart detainees clung to God as their last connection to life. Religiosity was a collective experience that all prisoners in Tazmamart shared, but alTalīdī chose to downplay other prisoners' experience of religious renewal in prison and elevate al-Maghūtī as a role model of faith, showing the risks associated with the Islamisation of memory. Islamising memory requires religious iconicity, which al-Maghūtī was able to give to al-Tajdìd's readers.

\section{A comparative discussion: Sụjūn wa-ashjān and Wa-ya'lūṣaw al-'ādhān min jạ̣īmi Tazmamart}

Now that I have made these crucial distinctions between Islamist and Islamised memory, I draw on Sujūn wa-ashjān and Wa-ya'lū to analyse how these two types of memory are different in terms of politicisation versus depoliticisation, intense religiosity vs ordinary Islam, and addressing collective memory vs partisanship.

66 Al-Rāys 2001, 180, BineBine 2009, 70.

67 Al-Marzūqī 2003, 100.

68 BineBine 2009, 67.

69 Al-Rāys 2001, 119; 121; 180.

70 Ibid., 180. 


\section{Politicisation vs depoliticisation}

The above distinction between Islamist and Islamised memory has emphasised how Islamised memory grew out of a normal desire to fill the void left by the suppression of Islamist memory in Morocco. Most importantly for literary studies, however, is the effect that the medium of publication has on both mediating and shaping memory as is demonstrated in al-Tajdìd's creation of al-Maghūtī's religious persona. Despite this distinction between the two types of memory, there is an even more consequential difference between them in terms of their degree of politicisation. While Islamist memory is forged from political struggle that pitted the state against Islamist activists, Islamised memory only co-opts memories that are likely to lend themselves to Islamisation. The condition of struggle politicises Islamist memory, whereas the predicatory, educational, and spiritual outcomes of Islamised memory depoliticise it.

Muștafā al-Ḥasnāwī's Sụjūn wa-ashjān and al-Muffaḍḍal al-Maghūtī/Bilāl al-Talīdì's Wa-ya'lū exemplify the differences between these two types of memory in terms of politicisation. For instance, Sujjūn wa-ashjān stakes out strong political positions vis-à-vis the security apparatus, the justice system, the state, and even the king. Starting from the first chapter entitled 'Asal laban karmūs hindī (Honey milk prickly pears), al-Ḥasnāwī asserts that his memoir represents "that which we experience living in a big prison named Morocco." The narrator demonstrates the political nature of his arrest by underlining the role that the triumvirate of intelligence, judiciary police, and the media played in orchestrating his arrest on charges of terrorism. ${ }^{72}$ To give a more political tone to his arrest and its consequences, al-Ḥasnāwī wonders about the significance of being summoned to the police station on May 16. Since 2003, May 16 has been associated with the terrorist attacks in Casablanca. Al-Ḥasnāwī cannot stop wondering: "I don't know why they chose May 16 to summon me to al-Ma'ārîf police station. Is this related to a desire to keep this date alive by keeping this dossier open or is it just a coincidence?"73 The date gives a strong political charge to al-Ḥasnāwī's arrest. To further depict the politics of his charge, alḤasnāwī includes a reimagined version of Scheherazade's story in his book. The story, this time, includes an incorruptible journalist whom "the sultan decided to imprison for forming a terrorist cell and leading an invisible criminal gang." ${ }^{\$ 4}$

\footnotetext{
71 Al-Ḥasnāwī 2018, 23.

72 Ibid.

73 Ibid., 13.

74 Ibid., 28.
} 
The journalist and the accusations resemble al-Ḥasnāwī and his experiences with the Moroccan state. The political nature of Sujūn wa-ashjān is expressed throughout in the critical tone it takes towards Moroccan authorities.

Al-Maghūtī's biography, Wa-ya 'lū, on the other hand, is oblivious to politics and refrains from making any critical statements about the political situation in the country. For instance, al-Maghūtì declares "I believe that the army should be at the service of the nation. The questions of reform, change or even the revolution, if they were justified, are the province of politicians and the army has nothing to do with them." ${ }^{" 75}$ Even forty years after the events, al-Maghūtī still reiterates "my simple conviction that I believe in is that the protection of the monarchy in Morocco is equivalent to the protection of the nation." ${ }^{76}$ Rare are the occasions when al-Maghūtī expresses a strong political opinion. One such occasion occurs when he talks about his unjust trial and underlines that he "didn't know Dlimi and [he] was not his enemy either, but [he] didn't know how he intervened at the last minute, changed the panel of judges, and transformed [his] innocence into twenty years." 77 The closest al-Maghūtī's memoir comes to voicing a critical opinion occurs in his description of how Nancy Touil, an American citizen and wife of al-Maghūtī's cellmate Commandant Mbark Touil, lobbied the American authorities to release the prisoners. Al-Maghūtì’s says

the political moment was opportune for us to reveal the injustice inflicted on us, and it was the moment we chose to write the famous letter that Colonel Touil smuggled out of jail and that reached his American wife. This was the inconvenient letter that stripped naked the 'democratic' and 'human rights' pretences of the official parties. ${ }^{78}$

Apart from these moments of lament, Wa-ya'lu is a depoliticised memoir that focuses on al-Maghūtī's introspective journey through the catastrophe of arrest, trial, and disappearance after his participation in the second coup d'état against King Hassan II in 1972. However, even this minor criticism of the state is neutralised by the statement that "King Hassan II was brave when he liberated us. He was generous when he ordered the Ministry of Human Rights to grant us all our rights." ${ }^{79}$ Thus, al-Maghūtì and al-Talīdī, who co-authored the memoir, chose to absolve the king of his responsibility for the unjust decision to send fifty-eight soldiers and officers to their certain death in Tazmamart. While the memoir

75 Al-Talīdī 2009, 95.

76 Ibid.

77 Ibid., 97.

78 Al-Talīdī 2009, 154.

79 Al-Ḥasnāwī 2018, 174. 
confers questionable praise on King Hassan II, it criticises the Advisory Council on Human Rights, taking pains to avoid addressing direct criticism to those who were really responsible for human rights violations. This reluctance to politicise further demonstrates that it was more important for the Harakat al-Tawhìd waal-Ișlāh to teach Islamist disciples perseverance and true faith than to denounce the misconduct of the Moroccan state during the Years of Lead.

While al-Maghūtī is politically passive, al-Hasnāwī uses his Islamist memoir to depict the security machinations behind his imprisonment and trial for terrorism. Al-Ḥasnāwī foregrounds the conjunction between his Islamist belief and his struggle for political liberation, writing that

[i]t's true that I am not a salfi jihādī (jihadist Salafi) as some intelligence newspapers accused me falsely. However, I am a journalist with a combative spirit: I am combative because of my interest in my country's issues and my people's anxieties and demands. ${ }^{80}$

He comments on his exchanges with his interrogators and writes: "[B]eyond the respectful treatment and the good intentions, let's delve into some details that were only the visible part of the iceberg of a vile conspiracy woven by the intelligence services" and the press subservient to them. ${ }^{81}$ For al-Hasnāwī, although it was less brutal physically, authoritarianism continues to function in the same manner it did during the Years of Lead. The pervasive fear of the authoritarian system is evident in the behaviour of the lawyers and civil society activists who refused to support him in his effort to prove his innocence of terrorism. To hear al-Ḥasnāwī tell it, Morocco has become a veritable prison. In his letter to a friend, who is also a journalist, he compares prohibitions in prison with the prohibitions that hit Moroccan society outside prison and writes that

you live in a big prison with a long list of prohibitions, but do you know that the difference lies in the fact that you are on probation and that you enjoy things that are prohibited for prisoners, but only temporarily because this nation is a big prison, and all the children of my country are prisoners. ${ }^{82}$

\section{Ordinary religiosity vs contrived religiosity}

Although both $W a-y a ' l \bar{u}$ and Sujūn wa-ashjān make references to Islam, there is a fundamental difference between their approaches to religiosity. While Islamist

\footnotetext{
80 Al-Ḥasnāwī 2018, 38.

81 Ibid., 14.

82 Ibid., 48.
} 
activism was the cause of al-Ḥasnāwì's arrest on charges of terrorism and imprisonment, Islam was never a factor in al-Maghūtī's eighteen-year plight in Tazmamart. And religiosity plays out differently in the two memoirs. Wa-ya'lü's investment in depicting al-Maghūtī as an embodiment of Islam is evident from the use of the word Allah over one hundred and eighty times in the book. This repetition is meant to demonstrate al-Maghūtī's deep faith as well as his destiny to serve as a role model for the true Islamic belief. For instance, Wa-ya'lu lays emphasis on al-Maghūtī's memorisation of the Quran, which he recited at an early age during Friday prayers in his village of Bāb Tāza. The fact that he made the call to prayer during his childhood - a habit that he continued in Tazmamart - is also used to depict al-Maghūtī as a 'super-believer'. To reveal alMaghūtī's extraordinary faith, the memoir describes how this deep religiosity stayed with him throughout the years he spent as a student in the northern city of Tétouan, away from his family's village, as well as during his training in France and the United States to become a pilot in the Moroccan Air Force. Even as an adult, religion was pivotal for al-Maghūtī, as this account shows how he spent the month of Ramadan away from non-fasting colleagues before the coup in 1972:

So, I spent almost a month in Bāb Tāza. Between the company of the family and taking care of their affairs, between the mosque and reading the Quran, I recovered reciting the Quran and calling for prayer at the mosque as well as the sweetness of collective evening prayer. ${ }^{83}$

Al-Maghūtī's religiosity is manifested in his absolute adherence to Islamic dietary restrictions, such as abstaining from alcohol and pork, even during his extensive stays abroad, which is meant to show his profound commitment to Islam regardless of any social and cultural pressure. ${ }^{84}$ Moreover, al-Maghūtī's chastity figures prominently in Wa-ya'lū's depiction of his abstention from premarital relationships, both sexual and sentimental, in Morocco and abroad. These strategies paint al-Maghūtī as a role model for Muslims to emulate, especially given the ordeal that he would survive in Tazmamart. The story that $W a-$ ya'lū tells aims to demonstrate that faith gave al-Maghūtī the necessary strength to survive in captivity for eighteen years.

Contrary to Wa-ya'lū, Sujūn wa-ashjān depicts a normal political activist who records the ups and downs of being unjustly imprisoned. Instead of any self-aggrandisement, al-Ḥasnāwī approaches his carceral situation realistically,

83 Al-Talīdī 2009, 47.

84 Ibid., 38-39; 55. 
without exaggeration. In a very telling scene, al-Ḥasnāwī informs his readers that he completed the recitation of the Quran twice while he was in police custody, but he also declares that the Quran could not substitute his love for writing because, in his words, "my pen was the only thing I wished I had in my cell." ${ }^{85}$ Rather than mulling over Islam or trying to show how his faith relieved him of the burden of physical imprisonment, al-Hasnāwī proceeds to build an intersectional network of human rights activists of all backgrounds to defend his innocence. Instead of relying solely on faith and spirituality in jail, alHasnāwī puts much emphasis on action that draws on a universal understanding of human rights. For instance, he reaches out to former Marxist-Leninists, Islamist lawyers, as well as human rights activists, to convince them to join the committee established to defend him. These connections are not always smooth or productive, but they demonstrate how al-Ḥasnāwī was able to transcend the limitations of Islamism to enter into conversation with all sections of society. When he sensed an attempt to misrepresent his statement about his Islamist background by a former Leninist-Marxist prisoner he had reached out to, al-Ḥasnāwī responded

I informed you that I am an Islamist so that you understand that I have no problem of communication with leftists, Jews or atheists. I informed you that I am an Islamist to demonstrate to you my openness, [my readiness for] communication and [my wish for] dialogue, in order to talk to you about my complaint. It's us who feel the condescension, marginalisation and exclusion in the other's talk with us. ${ }^{86}$

Al-Hasnāwī's memoir does not try to depict the life of a hermit or a spiritual man. It is instead the story of an Islamist activist's pragmatic journey inside an authoritarian state's carceral system. Unlike al-Maghūtī, for whom the Quran was "the treatment for all psychological ills that could befall a human being", ${ }^{87}$ al-Ḥasnāwī does not slip into any idealistic representations of Islam. For example, his description of the dangers inherent in the various Jihadist misinterpretations of Islam is a potent example of his critical approach. Al-Hasnāwī does not shy away from describing Jihadist Salafis as suffering from a "very complex ignorance and calcified stupid thought and dry stubborn character" ${ }^{88}$ Additionally, al-Ḥasnāwī sheds light on the lack of even the most rudimentary

\footnotetext{
85 Al-Ḥasnāwī 2009, 18.

86 Al-Ḥasnāwī 2018, 65.

87 Al-Talīiñ 2009, 112.

88 Al-Ḥasnāwī 2018, 113.
} 
education among Salafis, ${ }^{89}$ harshly criticising their misinterpretations of Islam. As a result, al-Ḥasnāwī is an Islamist activist whose memoirs are a critical account of both the state and flawed offshoot of Islamism.

\section{Partisan memory vs collective memory}

Their varied degrees of partisanship form another important distinction between Islamist from Islamised memory. A comparative analysis of the motivations underlying the publication of Wa-ya'lū and Sujūn wa-ashjān indicates that Islamised memory is partisan because it addresses a group of adepts or disciples, whereas Islamist memory is more open to addressing an entire society. $W a$-ya'lu made use of an individual memory of state violence to educate the followers of Harakat al-Tawhìd wa-al-Ișlāh. The now-defunct al-Tajdìd was only read by the followers of Harakat al-Tawhìd wa-al-Ișlāh who also happened to be sympathisers of the Justice and Development Party, and this partisanship was fundamental to the way al-Maghūtī's memoirs were narrativised in a style that depicts an overly pious al-Maghūtī. The impact this Islamist newspaper intended with the publication of Wa-ya'lū was not an end to Morocco's abysmal human rights situation, but a larger moralisation of society and politics through the 'ibra (lesson) that al-Maghūtī's life story represents. For instance, at no time does al-Talīdī, in his long introduction, say anything about human rights, but he seizes every opportunity to remind his readers about the religious angle the book takes. ${ }^{90}$ This bias is made even clearer by al-Talìdì's pre-emptive dismissal of criticism in claiming that it is sufficient for him that he "pioneered writing from this new angle or added to the credit of the Islamic literature other writings in addition to the writings of Najīb al-Kilāni and Aḥmad Rā'if, among others." ${ }^{11}$ As such, Wa-ya'lū is already enmeshed in a system of references to Islamist prisoners and Islam-focused objectives that narrow both its readership and its effects after publication. That said, it should not be assumed that these are alMaghūtî's goals or choices, because the media outlet that serialised his memoirs, and the journalist to whom he entrusted his memories, had a clear partisan point of view, which al-Maghūtī may not have shared.

Another way partisanship manifested itself in $W a-y a$ ' $l \bar{u}$ is through the erasure of the political context that made human rights violations in Morocco possi-

89 Al-Ḥasnāwī 2018, 113-24.

90 Al-Talīdī 2009, 5.

91 Ibid. 
ble. Wa-ya'lū makes no reference to the political situation in Morocco during the Years of Lead, and the entire book is detached from the struggles that took place in the country in the 1960s and the 1970s. Not even the Equity and Reconciliation Commission, which was put in place in 2004, garners any mention in the memoir. This is not surprising, however, given how vehemently the founder of the Justice and Development Party, Dr. 'Abd al-Karīm al-Khațib, reacted to the establishment of the ERC.92 Al-Tajdìd refocused the Tazmamart story on the mystical and faithful dimension in a way that did not clash with the party's position toward the Years of Lead. Partisan memory presents al-Maghūtī as someone who survived unjust incarceration thanks to his extraordinary faith. His experience was only serialised because it demonstrates the cruelty of the violations of human rights that took place in Morocco during the Years of Lead, and because it reinforces the Islamist readership's belief and trust in God.

However, unlike al-Talīdī's Islam-focused rendering of al-Maghūtī's experience, al-Ḥasnāwī's Sujūn wa-ashjān is oriented towards a future collective memory, which documents the injustice and criticises the dysfunctional system in Morocco. The uniquely personal or spiritual journey of Wa-ya'lū is replaced by an analysis of various state injustices and abuses in Sujūn wa-ashjān. For example, when he was denied royal pardon, al-Hasnāwī writes that he had "to be born French, Spanish, 'Israeli' (...) or even a supporter of the POLISARIO Front (...) to be granted royal amnesty." ${ }^{93}$ The generalisation that al-Hasnāwī makes from his own case reveals a lot about the way he draws on his experience of imprisonment to demonstrate that the majority of Moroccans are subjected to this injustice: "Despite loneliness, I find myself lucky inside this cell because thousands of this nation's children are crammed with their children in similar cells or even smaller, and some of them don't even have one." ${ }^{\prime 4}$ He takes on "corruption, authoritarianism, and bleakness", which "remind [him] that the prison is outside these walls." 95 For him, the entire Moroccan society was a victim of imprisonment. In al-Ḥasnāwī's words, despite all the abuses they commit, Moroccan officials

still find time to talk about human rights and freedoms, welcome the High Commission for Human Rights, refute international human rights reports, and raise their voices in their clubs [to extol] the great reforms. They contrive to talk about new generations of [human]

92 Dr. El Khatib created a lot of controversy because of his anti-ERC positions in 2004 and 2005. See Aḥiyātī 2004, ALM 2005, El Guabli 2017, 130.

93 Al-Ḥasnāwī 2018, 32.

94 Ibid., 33.

95 Ibid., 34. 
rights in the meantime as new generations [of Moroccans] are being deprived of their rights. ${ }^{96}$

Al-Ḥasnāwī draws attention to the disconnect between the state's discourse on human rights and the constant violation of these rights in the lived reality of the Moroccan population. Through and through, Sujūn wa-ashjān recounts the story of an abuse of judicial and security authority to raise broader questions and critical reflections on Moroccan society's suffering from social injustice, exclusion, corruption, and authoritarianism. The memoir makes a crucial point about injustice as a mechanism of governance in Morocco. Memory, for al-Ḥasnāwī, serves as a space for challenging human rights abuses. State violence, such as that suffered by al-Ḥasnāwī, does not simply come to an end by itself, but requires multiple remedies, including reminding both abusers and society of the fact of their abuse.

\section{Conclusion}

In this article, I have proposed the conceptualisation of two types of Islamrelated memories that emerged in post-1999 Morocco. Using two memoirs of former political detainees, Wa ya'lū and Sujūn wa-ashjān, I have demonstrated that Islamist memory, on the one hand, is oriented toward an inclusive collective memory, and that Islamised memory, on the other hand, is a partisan memory that places predication and spiritual improvement of disciples above the needs of the larger society. Islamist memory is an advocating memory whereas Islamised memory is a hermitic memory, which has dire implications for democratisation and societal transformation.

Morocco's rich social memory has been primarily shaped by remembrances of the monarchy, Marxist-Leninists, and Tazmamart prisoners. These three gatekeepers of the past have succeeded at using all the advantages offered by various media, including writing and film, to shape cultural and social memory, even to the point of pushing Moroccan Islamists to the margins of the Moroccan memory landscape. This conceptualisation of Islamist and Islamised memory will further complicate our understanding of the presence of these memories in cultural memory and draw attention to the intersections between state violence, religion, and Islamism in the country. Although the literary corpus I have examined is limited, it is important to emphasise that more Islamist testimonial prison

96 Al-Ḥasnāwī 2018, 34. 
literature can be expected in the coming years due to the ongoing security campaigns against Islamists, mainly on terrorism charges or other politically motivated accusations. Only the future will show how deeply these Islamist and Islamised renderings of state abuses will seep into the larger social and cultural memory, or whether they would remain under the embargo of unavailability to the majority of non-Islamist Moroccan readerships. Either way, the conceptualisation of these two types of memory will help to chart a different path for other scholars to explore the complexities of inventing, redirecting, and reshaping Islam-based memory in post-colonial Morocco, where the relationship between politics, Islam, and memory is a deeply neglected area in need of critical examination. 


\section{Bibliography}

Aḥīyātī, Maḥmūd. 2004. “Waṣfa al-ḍaḥāyā bi 'al-ṣa ‘ālīk' wa-'taraḍa 'alā ta 'wị̄ihim bi-al-amwāl.” Alriyad, December 28, 2004. http://www.alriyadh.com/4206, accessed July 1, 2020.

ALM. 2005. "El Khatib charge Ben Barka." Aujourd'hui Le Maroc, November 30, 2005. https:// aujourdhui.ma/focus/el-khatib-charge-ben-barka-37319, accessed July 1, 2020.

Assmann, Jan. 2008. "Communicative and Cultural Memory." In Cultural Memory Studies: An International and Interdisciplinary Handbook, edited by Astrid Erll, Ansgar Nünning, and Sara B. Young, 109-18. Berlin: De Gruyter.

Bāṭmā, al-'Arabī. 1995. Al-raḥīl. Casablanca: Dār Tubqāl.

BineBine, Aziz. 2009. TAZMAMORT: Dix-huit ans dans le bagne de Hassan II. Paris: Delanoë.

Belqāsim, Ḥakīmī. 2001. Kitābāt bada'at min ḥayyi al-i`dām. Casablanca: Manshūrāt Jarīdat alNashra.

Belqāsim, Ḥakīmī. 2005. “Ḥakīmī Belqāsim ...niẓām al-ḥukm al-maghribī.” Aljazeera, November 27, 2005. https://bit.ly/3blNuqq, accessed March 26, 2019.

Chaarani, Ahmed. 2004. La mouvance islamiste au Maroc: Du 11 septembre 2001 aux attentats de Casablanca du 16 mai 2003. Paris: Karthala.

Ḍarīf, Muḥammad. 1999. Al-Ḥaraka al-Islāmīyah: Al-nash'ah wa-al-tațawwur. al-Dār al-Bayḍā': Manshūrāt Jarīdat al-Zaman.

De Cesari, Chiara, and Ann Rigney. 2014. Transnational Memory: Circulation, Articulation, Scales. Berlin: Walter de Gruyter.

Dialmy, Abdessamad. 2000. “L’Islamisme Marocain: Entre révolution et intégration.” Archives de Sciences Sociales des Religions 45, no. 110: 5-27.

El Ayadi, Mohammed. 2015. Les deux visages du roi: Le monarque et le Commandeur des croyants. Casablanca: Éditions la Croisée des Chemins.

El Guabli, Brahim. 2017. "Testimony and Journalism: Moroccan Prison Narratives." In The Social Life of Memory: Violence, Trauma, and Testimony in Lebanon and Morocco, edited by Norman Saadi Nikro, and Sonja Hegasy, 113-44. New York: Palgrave Macmillan.

El Guabli, Brahim. 2020a. “The absent perpetrators: Morocco’s Failed Accountability, Tazmamart Literature and the Survivors' Testimony for their Jailers (1973-1991)." Violence: An International Journal 1, no. 1: 80-101.

El Guabli, Brahim. 2020b. “Joint Authorship and Preface Writing Practices as Translation in post-'Years of Lead' Morocco." In The Routledge Handbook of Translation and Activism, edited by Rebecca Ruth Gould, and Kayvan Tahmasebian, 237-57. New York: Routledge.

Erll, Astrid, and Ann Rigney. 2009. Mediation, Remediation, and the Dynamics of Cultural Memory. Berlin: Walter de Gruyter.

Halbwachs, Maurice. 1992. On Collective Memory. Chicago: University of Chicago Press.

Hammoudi, Abdellah. 1997. Master and Disciple: The Cultural Foundations of Moroccan Authoritarianism. Chicago: University of Chicago Press.

Hānī, Drīs. 2011. "Al-islāmiyyūn al-maghāriba wa ḥarakat 20 fibrāyer." Hespress, December 31, 2011. https://www.hespress.com/writers/44401.html, accessed June 29, 2020.

Ḥaqīqī, Ṃuḥammad. 1995. "Yawmiyyāt sajīn," al-Jisr 28 (July-August 1995).

Ḥaqīqī, Ṃuḥammad. 2015. “Muḥammad Ḥaqīqī yațraḥu mubādara min ajl ị̣yā’ al-rūḥ li-jam 'iyyat al-mu 'taqalīn al-islāmiyyīn al-sābiqīn khilāla sanwāt al-rașāṣ." Anfāspress, March 4, 2015. https://anfaspress.com/news/voir/18409-2015-03-04-07-58-09, accessed March 23, 2019. 
al-Ḥasnāwī, Muṣtfā. 2018. Sujūn wa-ashjān: hikāyāt min warā' al-quḍbān. Rabat: Shams Print. Human Rights Watch. 2005a. "Nashāṭ hay’at al-inșāf wa-al-muṣālaḥa." HRW Report, November 2005. https://www.hrw.org/legacy/arabic/reports/2005/morocco1105/7.htm, accessed March 23, 2019.

Human Rights Watch. 2005b. "La commission marocaine de vérité: Le devoir de mémoire honoré à une époque incertaine.” HRW Report, November 2005. https://www.hrw.org/ reports/morocco1105frwcover.pdf, accessed June 29, 2020.

Instance Équité et Réconciliation. 2009. Rapport Final: Vérité, Équité et Réconciliation. Rabat: Publications du Conseil Consultatif des Droits de l'Homme.

Laâbi, Abdellatif. 1982. Le chemin des ordalies. Paris: Denoël.

Lḥū, Aḥmad. 2021. 'Á'id min al-mashraḥa. Rabat: Dār al-Wațan.

al-Marzūqī, Ạ̣mad. 2003 Tazmamart: Al-zinzāna raqm 10. Casablanca: Tarik Editions.

Mhtād, 'Abd Arraḥīm. 2020. "Al-Tārīkh al-sirrī li-al-shabība al-islāmiyya (6): Lughz ightiyyāl "umar binjillūn.” Al-Șabāḥ, May 14, 2020. https://assabah.ma/470335.html, accessed May and June 2020.

Mohsen-Finan, Khadija. 2007 "Mémoire et réconciliation nationale au Maroc.” Politique Étrangère 2: 327-38.

Mu'assasat Muḥammad al-Sādis lil-‘Ulamā’ al-Afāriqa. 2015. "Zahīr sharīf yata‘allaqu bi-iṇdāth mu'assasat muḥammad al-sādis li-al-‘ulamā' al-afāriqa.” fm6oa. https://www.fm 6oa.org/\%d8\%b8\%d9\%87\%d9\%8a\%d8\%b1, accessed June 29, 2020.

al-Rāys, Muḥammad. 2001. Min Skhirāt ilā Tazmamārt tadhkiratu dhahāb wa iyāb ilā-al-jahịm. Casablanca: Afriqiā al-Sharq.

Rollinde, Marguerite. 2002. Le mouvement marocain des droits de l'Homme, entre consensus et engagement citoyen. Paris: Karthala.

Serhane, Abdelahak. 2005. Kabazal-Les Emmurés de Tazmamart: Mémoires de Salah et Aïda Hachad. Casablanca: Tarik Editions.

al-Shāwī, 'Abd al-Qādir. 2010. Kāna wa-khawātuhā, Casablanca: Nashr al-Fanak.

Slyomovics, Susan. 2005. The Performance of Human Rights in Morocco. Philadelphia: University of Pennsylvania Press.

Slimānī, Tawfīq. 2018. “1067 mu‘taqlan bayna salafĩ wa ‘ā’id min sūriā.” Alyaoum24, February 2, 2018. https://www.alyaoum24.com/1038779.html, accessed June 29, 2020 [no longer accessible].

al-Talīdī, Bilāl. 2009. Wa-ya'ū șawt al-adhān min jahịm Tazmāmart: mudhakkirāt al-mu'taqal al-Mufaḍụal al-Maghūtī. Rabat: Manshūrāt al-Tajdīd.

Valensi, Lucette. 1990. "Le roi chronophage. La construction d'une conscience historique dans le Maroc postcolonial.” Cahiers D’Études Africaines 30, no. 119: 279-98.

Wahbi, Abdellatif. 2020: “Imārat al-mu’minīn 'islām siyyāsī'..w-mllī nkūn amīn ‘ām ghanṭleb Imalik y'fū 'lā 'mu 'taqalī rrīf'." Goud, January 23, 2020. https://www.goud.ma/\%D9\% 88\%D9\%87\%D8\%A8\%D9\%8A, accessed June 29, 2020.

Waltz, Susan E. 1995. Human Rights and Reform: Changing the Face of North African Politics. Los Angeles: California University Press.

Wld al-Qābla, Drīs. 2006. “Hay’at al-inșāf wal-muṣālaḥa wal-ḥaqĩqa l-ma‘ūqa.” Al-Ḥiwār alMutamaddin, January 23, 2006. http://www.m. ahewar.org/s.asp?aid=55471\&r=0, accessed March 20, 2019.

Zeghal, Malika. 2008. Islamism in Morocco: Religion, Authoritarianism, and Electoral Politics. Princeton: Markus Wiener Publishers. 